Article

\title{
Clipping Forage Sorghum Twice and Nitrogen Topdressing Offer an Option for Dual-Purpose Use for Cover Cropping and Fodder in Mixed Crop/Livestock Farming Systems
}

\author{
Kudzayi Janhi@, Zimkhitha Matshaya, Cornelius Chiduza * and Lindah Muzangwa \\ Department of Agronomy, University of Fort Hare, Private Bag X1314, Alice 5700, South Africa; \\ kudziejanhi@gmail.com (K.J.); zikhonamatshaya2@gmail.com (Z.M.); Lindamuza@live.com (L.M.) \\ * Correspondence: cchiduza@ufh.ac.za; Tel.: +27-789856220
}

Received: 18 November 2019; Accepted: 15 December 2019; Published: 20 December 2019

\begin{abstract}
Management practices that promote dual-purpose use of cover crops as forage and soil cover can encourage adoption in mixed smallholder (SH) farming systems. This study investigated the feasibility of dual-purpose use of forage sorghum (Sorghum bicolor $x$ Sorghum bicolor var. sudanense) by testing the effects of clipping frequency and nitrogen $(\mathrm{N})$ topdressing on the root biomass, crude protein $(\mathrm{CP})$, acid detergent (ADF), and neutral detergent fiber (NDF) in the greenhouse and vegetative biomass on the experimental farm station. Four levels of clipping were tested: not clipped (C1), clipped once (C2), twice (C3), and thrice (C4). Nitrogen topdressing had two levels: with (N1) and without (N0) recommended supplementary N. Results show that absence of $\mathrm{N}$ topdressing significantly $(p<0.05)$ increased root biomass in $\mathrm{C} 2$, while increasing clipping frequency significantly $(p<0.001)$ decreased root biomass. During the growing period, $\mathrm{N}$ topdressing significantly $(p<0.001)$ increased $\mathrm{CP}$ content in $\mathrm{C} 3$ and $\mathrm{C} 4$ and $\mathrm{NDF}(p<0.01)$ content in C4. At the termination stage, there was a significant interaction between clipping frequency and $\mathrm{N}$ topdressing on the biomass yield obtained in both 2016-2017 $(p<0.05)$ and 2017-2018 $(p<0.001)$, respectively. Clipping twice and $\mathrm{N}$ topdressing emerged as the best management practice for the dual-purpose of soil cover and livestock feed.
\end{abstract}

Keywords: biomass yield; livestock forage; smallholder farm; soil cover

\section{Introduction}

High levels of soil erosion are compounded by inherent low levels of soil fertility. Moreover, the practice of low input production systems has largely contributed to the low productivity of crops and livestock, particularly in smallholder (SH) farms of the central Eastern Cape (EC) province of South Africa (SA) [1,2]. Crop residues that could be used for soil cover in conservation agriculture (CA), a technology deemed to be a remedy for soil degradation, are rather used for livestock feed due to a decrease of pasture productivity over years [3]. Conservation agriculture is a technology which entails the simultaneous practice of three principles; minimum tillage, diversified crop rotation, and permanent organic cover [4]. Regardless of the recorded advantages of CA, reduced success has been recorded in the EC due to the failure to produce sufficient amounts of biomass for soil cover. This is despite the fact that a good supply of crop residues to soil has a number of benefits, such as reduced water run-off, and increased rainfall infiltration and water retention [4]. Other benefits include reduced weed infestation [5] and long-term advantages such as increased soil organic carbon (SOC) [6]. High-yielding cover crops such as forage sorghum can address both soil degradation and challenges associated with shortages in forage, given that proper management strategies are established. The management 
strategies may entail periodic harvesting of cover crops for livestock feed by subjecting them to varying clipping frequencies.

Literature on using forage sorghum for this dual purpose remains limited. The majority of studies have focused on using cover crops for fodder purposes. As such, the first clipping date and clipping schedules in these studies do not accommodate the recovery period needed by the cover crops for residue biomass production at the final harvest. Furthermore, there are discrepancies in the minimum amount of biomass residues needed in the cropping systems to promote CA benefits. Several studies have suggested residues of $2 \mathrm{tha}^{-1}$ as the minimum threshold for soil cover purposes. Working in a semi-arid region that receives about $580 \mathrm{~mm}$ of rainfall per year, Choudhary et al. [7] showed that water infiltration and retention increased significantly with $2 \mathrm{t} \mathrm{ha}^{-1}$ of crop residue. Similarly, research conducted by Swella et al. [8], Nichols et al. [9], and Ranaivoson et al. [10] suggested $2 \mathrm{t} \mathrm{ha}^{-1}$ as the minimum threshold for improving water infiltration and retention, and also the ideal level for reducing soil loss and weed infestation.

Livestock feed is regarded as of high quality when crude protein (CP) is high and when crude fiber, including both acid detergent fiber (ADF) and neutral detergent fiber (NDF), is low. Forages with CP content above $8 \%$ and ADF and NDF content below 45 and $65 \%$, respectively, are recommended for livestock feed purposes [11]. There are contradicting findings on the effect of clipping frequency on grazing quality. For example, whilst Kumar and Chaplot [12] and Rana et al. [13] stated that sorghum clipped twice had higher crude fiber content as compared to being clipped once, Roy and Khandaker [14] observed no change in crude fiber with respect to clipping frequency.

Several studies have shown that $\mathrm{N}$ addition increases $\mathrm{CP}$ content, as well as improves biomass yield [15-17]. However, knowledge on the effects of $\mathrm{N}$ on promoting forage sorghum regrowth remains scarce. According to Almeida et al. [18], regrowth of grasses after herbage clipping is largely determined by the non-structural carbohydrates (NSC). After herbage removal, NSC are contained in plant reserves, such as the roots and stolon [19]. If roots contain NSC required for the regrowth, the effect of clipping frequency on root biomass should, therefore, be investigated. Furthermore, Mapfumo et al. [20] stated that the response of roots to clipping of herbage differs from one grass species to another. Research conducted by Liu et al. [19] suggests that excess $\mathrm{N}$ decreases carbohydrates reserves, and this negatively impacts regrowth.

Therefore, in order to foster active adoption of forage sorghum cover cropping, management practices that provide minimum required crop residue biomass for soil cover benefits whilst simultaneously meeting livestock feed demand should be established. This study was carried out to investigate the best management practices for forage sorghum, for the dual use of soil cover and livestock feed. The specific objectives were: (i) evaluate the effect of clipping frequency and $\mathrm{N}$ topdressing on the root biomass of forage sorghum (ii); evaluate the effect of clipping frequency and $\mathrm{N}$ topdressing on the grazing quality of forage sorghum (iii); evaluate the effect of clipping frequency and $\mathrm{N}$ topdressing on the vegetative biomass yield of forage sorghum.

\section{Materials and Methods}

Two experiments were conducted: one in the greenhouse to study root biomass (ADF and NDF), and the other in the field to study biomass accumulation.

\subsection{Greenhouse Pot Experiment}

\subsubsection{Soil Sampling and Preparation}

In this study, soils were collected from a depth of $0-20 \mathrm{~cm}$ from the University of Fort Hare (UFH) Research Farm $\left(32^{\circ} 46^{\prime} 15.8^{\prime} \mathrm{S}\right.$ and $\left.26^{\circ} 50^{\prime} 52.3^{\prime} \mathrm{E}\right)$ for pot experiment in the greenhouse. Crop residues were cleared before taking soil samples. The soil was air dried for $72 \mathrm{~h}$, after which it was sieved through a $2 \mathrm{~mm}$ plate. The soil was thoroughly mixed before chemical analysis and experiment set up. 


\subsubsection{Soil Analysis}

The soil is of the Ritchie family of the Oakleaf form [21] and Eutric Cambisol according to the International Union of Soil Sciences (IUSS) Working Group World Reference Base for soil resources (WRB) [22]. Soils were analyzed for $\mathrm{pH}$ in water using the $\mathrm{pH}$ meter (Crison Instruments, Alella, Spain) following procedures outlined in the Agri-Laboratory Association of Southern Africa (AgriLASA) [23]. Soil organic carbon (SOC) was analyzed using the modified Walkley Black method [23] and total N was determined following the wet ashing procedure, as outlined by Mnkeni and Gichangi [24].

\subsubsection{Experimental Site, Treatments, and Experimental Design}

The pot experiment was conducted in a semi-controlled greenhouse, where one section received more sunlight than the other, at the University of Fort Hare (UFH) Research Farm. Plastic pots measuring $15 \mathrm{~cm} \times 30 \mathrm{~cm}$ in diameter were used and $8 \mathrm{~kg}$ soil was applied to each pot. The experiment evaluated two factors, clipping frequency and nitrogen topdressing $(\mathrm{N})$. Clipping frequency was at four levels; clipped only at termination (C1), once during the growing season and at termination (C2), twice during the growing season and at termination (C3), and thrice during the growing season and at termination (C4). Meanwhile, the $\mathrm{N}$ topdressing was also evaluated at two levels-with (N1) $\left(120 \mathrm{~kg} \mathrm{~N} \mathrm{ha}^{-1}\right)$ and without (N0)—-to make eight treatments. These were replicated three times and laid out as a randomized complete block design (RCBD). All pots received basal fertilizer as 2:3:4 (30) $+\mathrm{Zn}$ at a rate of $500 \mathrm{~kg} \mathrm{ha}^{-1}$ to supply $33 \mathrm{~kg} \mathrm{~N} \mathrm{ha}^{-1}, 50 \mathrm{~kg} \mathrm{P} \mathrm{ha}^{-1}$, and $68 \mathrm{~kg} \mathrm{~K} \mathrm{ha}^{-1}$ at planting stage. Treatments with $\mathrm{N}$ topdressing received similar additional amount of $120 \mathrm{~kg} \mathrm{~N} \mathrm{ha}^{-1} \mathrm{~N}$ topdressing, which was applied after each cut. Where more than one cut was made, the $\mathrm{N}$ topdressing was split-applied in equal amounts for each cut. The experiment was terminated at 90 days after emergence (DAE).

\subsubsection{Agronomic Practices}

Three seeds were planted into each pot on March 1, 2017, and thinned to leave one at 7 DAE. The basal fertilizer rate applied translated to $133 \mathrm{mg} \mathrm{N}, 200 \mathrm{mg} \mathrm{P}$, and $270 \mathrm{mg} \mathrm{K}$ pot $^{-1}$, using the conversion factor of 1 ha equaling 2 million $\mathrm{kg}$ of soil, as stated by Mehlich [25]. Nitrogen topdressing was only applied after the first clipping. The control treatment of $\mathrm{C} 1+\mathrm{N} 1$ was $\mathrm{N}$ topdressed at $28 \mathrm{DAE}$. Treatments receiving $\mathrm{N}$ topdressing were supplied with lime ammonium nitrate (LAN) $28 \%$ to achieve a rate of $120 \mathrm{~kg} \mathrm{~N} \mathrm{ha}^{-1}$ (480 $\mathrm{mg} \mathrm{N} \mathrm{pot}^{-1}$ ) for sorghum, as recommended by Sher et al. [26]. The pots were irrigated to field capacity every $48 \mathrm{~h}$. The experiment was terminated on June 10, 2017, after reaching $50 \%$ flowering.

\subsubsection{Data Collection}

Root biomass was measured at termination of the experiment. Pots were saturated with water for $24 \mathrm{~h}$, after which the roots were carefully detached from the soil and washed out under low pressure running water. The cleaned roots were placed on a clear filter paper and dried in an oven at $65{ }^{\circ} \mathrm{C}$ before dry biomass determination. Vegetative biomass samples for analysis of $\mathrm{CP}$, ADF, and NDF were collected 28, 42, and 56 DAE, respectively, and termination stage. At each clipping, stubble measuring $10 \mathrm{~cm}$ above the ground was left, as recommended by Department of Agriculture, Forestry and Fisheries (DAFF) [27]. Samples were oven dried at $65{ }^{\circ} \mathrm{C}$ to a constant mass, after which the dry mass was recorded. Grazing quality was measured by analyzing crude protein $(\mathrm{CP})$, acid detergent fiber $(\mathrm{ADF})$, and neutral detergent fiber (NDF) in all the clipped vegetative biomass. Crude protein was determined first by analyzing total $\mathrm{N}$ following wet ashing procedures outlined by Mnkeni and Gichangi [24]. The total $\mathrm{N}$ obtained was converted to $\mathrm{CP}$ using the equation: $\mathrm{CP}\left(\mathrm{g} \mathrm{kg}^{-1}\right)=$ total $\mathrm{N}\left(\mathrm{g} \mathrm{kg}^{-1}\right) \times 6.25$, as suggested by McDonald et al. [15]. Neutral detergent fiber (NDF) was determined through digestion of plant samples in a detergent solution and the predominant residues analyzed were lignin, cellulose, and hemicellulose. Acid detergent fiber was determined 
through digesting plant samples in sulfuric acid solution. The predominant residues were lignin and cellulose. The analysis for NDF and ADF was done using $\mathrm{ANKOM}^{200}$ with 65 rotations per minute agitation (ANKOM Technology).

\subsubsection{Data Analysis}

Nitrogen topdressing was added after the first clipping at $28 \mathrm{DAE}$, therefore the effect of $\mathrm{N}$ topdressing on $\mathrm{CP}, \mathrm{ADF}$, and NDF measured during the growing period was analyzed as a one-way analysis of variance (ANOVA) for C3 and C4, using the John's Macintosh Project (JMP) version 14.1 statistical package. The statistical model for the parameters measured during the growing period for $\mathrm{C} 3$ and $\mathrm{C} 4$ is given in the equation below:

$$
\gamma \mathrm{ijk}=\mu+\mathrm{ri}+\mathrm{fj}+\mathrm{eij}
$$

where $\mu$ grand mean, $r i=$ effect of ith replication, $f j=$ fertilizer effect $(j=0,1)$, and eij $=$ error component, independently and normally distributed with mean zero.

After the termination stage, the root and vegetative biomass, $\mathrm{CP}, \mathrm{ADF}$, and NDF content in the vegetative biomass samples were analyzed as two-way ANOVA using JMP version 14.1 statistical package. Mean separation was done using Tukey's honestly significant difference (HSD) test. Least significant difference (LSD) values were calculated using Tukey's HSD test at $5 \%$ significance level. The statistical model for the experiments at final harvest is given in the equation below:

$$
\gamma \mathrm{ijk}=\mu+\mathrm{ri}+\mathrm{cj}+\mathrm{fk}+(\mathrm{cf}) \mathrm{ijk}+\text { eijk }
$$

where $\mu$ grand mean, $r i=$ effect of ith replication, $c j=$ effect of clipping frequency $(j=1,2,3,4)$, $\mathrm{fk}=$ fertilizer effect $(\mathrm{k}=0,1)$, (cf) $\mathrm{ijk}=$ interaction between clipping frequency and fertilizer, and eijk = error component, independently and normally distributed with mean zero.

\subsection{Field Experiment}

\subsubsection{Experimental Site}

The study was carried out at the University of Fort Hare Research Farm $\left(32^{\circ} 47^{\prime} \mathrm{S}\right.$ and $\left.27^{\circ} 50^{\prime} \mathrm{E}\right)$. The farm lies at an average altitude of $508 \mathrm{~m}$ above sea level and has a warm, temperate climate, with an average annual rainfall of about $575 \mathrm{~mm}$ and an annual mean temperature of $18{ }^{\circ} \mathrm{C}$. The soils are deep and of alluvial origin, classified as Haplic Cambisol [22], with $64.2 \%$ sand, $16.0 \%$ silt, and $19.8 \%$ clay [28]. The soil at the initiation of the experiment had similar $\mathrm{pH}, \mathrm{SOC}$, and total $\mathrm{N}$ as reported for the pot experiment soils.

\subsubsection{Treatments and Design}

The field experiment evaluated the same factors and levels as described for the greenhouse pot experiment. The eight treatments were laid out in a randomized complete block design (RCBD) with three replications in two seasons of experimentation, in 2016-2017 and 2017-2018 summer seasons, respectively. The gross plot measured $47 \mathrm{~m} \times 19.75 \mathrm{~m}$, whilst the net plot size measured $5 \mathrm{~m} \times 5.25 \mathrm{~m}$.

\subsubsection{Agronomic Practices}

Land for the experiment was ploughed, disked, and rotovated before planting in both seasons of experimentation. Planting was done on 3 January 2017, in the first season, and on the 17 December 2017, in the second season. Forage sorghum seed was hand-drilled at a rate of $7 \mathrm{~kg} \mathrm{ha}^{-1}$ in furrows that were $0.75 \mathrm{~m}$ apart, as recommended by DAFF [27]. At planting, basal fertilizer 2:3:4 (30) $+\mathrm{Zn}^{+}$was applied as adopted for the greenhouse pot trial. The rainfall received and supplementary overhead irrigation applied in each of the two seasons are shown in Table 1. 
Table 1. Rainfall received and irrigation water applied $(\mathrm{mm})$ to the field trial during the 2016-2017 and 2017-2018 seasons.

\begin{tabular}{ccccc}
\hline & \multicolumn{2}{c}{ 2016-2017 } & \multicolumn{2}{c}{ 2017-2018 } \\
\hline Month & Rainfall (mm) & Irrigation $\mathbf{( m m )}$ & Rainfall (mm) & Irrigation (mm) \\
\hline December & - & - & 48.26 & 50 \\
January & 89.92 & 40 & 54.86 & 30 \\
February & 73.15 & 45 & 53.59 & 20 \\
March & 34.29 & 50 & 57.4 & 20 \\
April & 22.1 & 20 & 62.23 & 0 \\
\hline
\end{tabular}

In all the experiments, no chemical weed or pest control was used; as such, emerging weeds were controlled by hand hoeing. The experiments were terminated at $50 \%$ flowering stage by tractor rolling and application of glyphosate (isopropyl amine salt) herbicide at $4 \mathrm{~L} \mathrm{ha}^{-1}$. The termination dates were April 25 and April 3 in 2017 and 2018, respectively.

\subsubsection{Data Collection}

Vegetative biomass accumulation was collected at 28,42, and 56 DAE and at termination stage of the experiment. To collect the biomass, quadrats measuring $1 \mathrm{~m} \times 1 \mathrm{~m}$ were randomly thrown into the plot. All the vegetative biomass present within the quadrat was clipped to a height of $10 \mathrm{~cm}$ above the ground. The collected biomass was oven dried at $65^{\circ} \mathrm{C}$ until a constant mass was achieved, after which the dry mass was recorded.

\subsubsection{Data Analysis}

The seasons were tested for homogeneity of variance using the $F$ test. The results showed that the variances were not homogeneous at $p<0.05$. Therefore, the data for each season were analyzed separately for forage. The effect of $\mathrm{N}$ topdressing on the vegetative biomass measured during the growing period was analyzed as a one-way analysis of variance (ANOVA) for C3 and C4, using the JMP version 14.1 statistical package. The statistical model for the parameters measured during the growing period at $\mathrm{C} 3$ and $\mathrm{C} 4$ are given in the equation below:

$$
\gamma \mathrm{ijk}=\mu+\mathrm{ri}+\mathrm{fj}+\mathrm{eij}
$$

where $\mu=$ grand mean, $r i=$ effect of ith replication, $f j=$ fertilizer effect $(j=0,1)$, and eij $=$ error component, independently and normally distributed with mean zero

After final harvest, the vegetative biomass collected was analyzed with two-way ANOVA using JMP version 14.1 statistical package. Mean separation was done using Tukey's HSD test. LSD values were calculated using Turkey's HSD test at 5\% significance level. The statistical model for the experiments at final harvest is given in the equation below:

$$
\gamma \mathrm{ijk}=\mu+\mathrm{ri}+\mathrm{cj}+\mathrm{fk}+(\mathrm{cf}) \mathrm{ijk}+\text { eijk }
$$

where $\mu=$ grand mean, $r i=$ effect of ith replication, $c j=$ effect of clipping frequency $(j=1,2,3,4)$, $\mathrm{fk}=$ fertilizer effect $(\mathrm{k}=0,1),(\mathrm{cf}) \mathrm{ijk}=$ interaction between clipping frequency and fertilizer, and eijk = error component, independently and normally distributed with mean zero.

\section{Results}

\subsection{Soil Analysis Results}

The soil pH was 5.2 , SOC $0.63 \%$, and total $\mathrm{N}$ was $0.041 \%$. 


\subsection{Greenhouse Experiment}

\subsubsection{Root Biomass Results}

Figure 1 shows the interaction $(p<0.05)$ between clipping frequency and $N$ fertilization on the root biomass measured at termination. The findings of the study indicate that the application of $\mathrm{N}$ fertilizer reduced root biomass in C2 but had no such effect at C1, C3, and C4 (Figure 1). Highest root biomass was achieved in the control that was not clipped, but application of $\mathrm{N}$ did not make a difference. Results also reveal that the main effects of clipping frequency were significant $(p<0.001)$, whilst $\mathrm{N}$ topdressing main effects were not significant $(p=0.073)$. Generally, increasing clipping frequency significantly $(p<0.001)$ lowered root biomass.

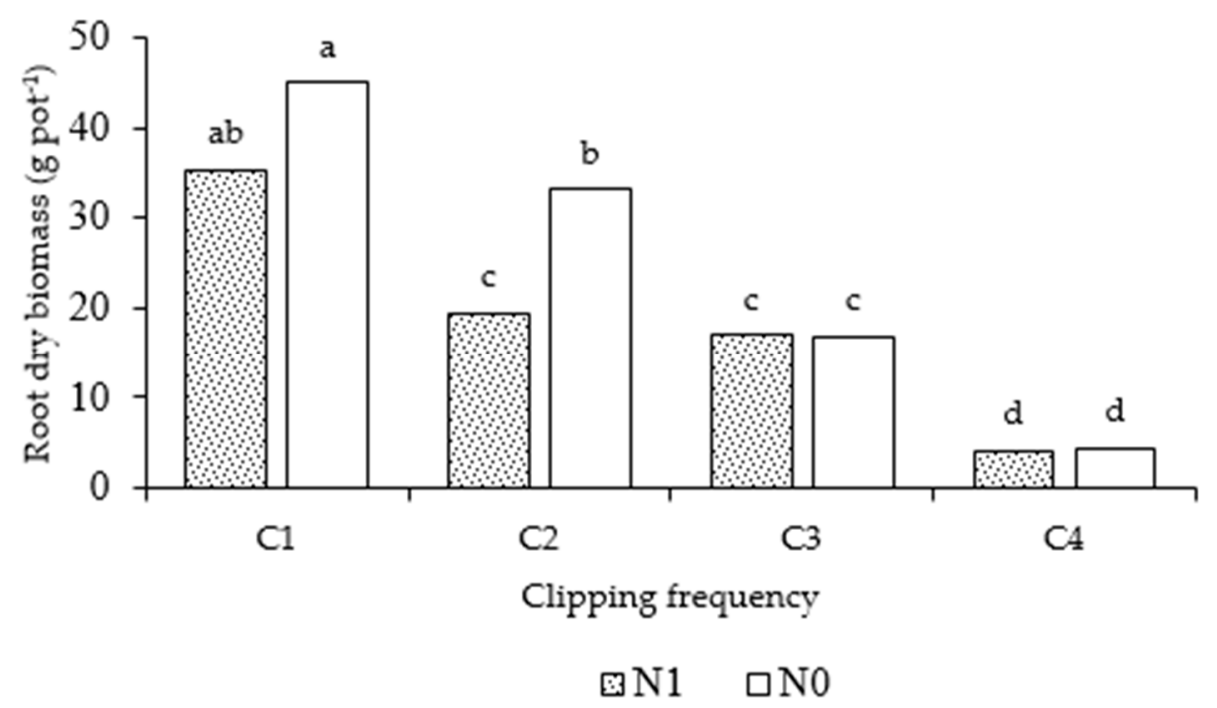

Figure 1. Interaction of clipping frequency and $\mathrm{N}$ topdressing on forage sorghum dry root biomass at 90 days after emergence. Different lowercase letters show significant differences at $p<0.05$, LSD $0.05=3.52$.

\subsubsection{Grazing Quality Measured during the Growing Period}

Nitrogen topdressing was applied after the first clipping, and so its effects were measured at C3 and C4. Application of $\mathrm{N}$ topdressing significantly $(p<0.001)$ increased $\mathrm{CP}$ in $\mathrm{C} 3$ and $\mathrm{C} 4$. On the other hand, $\mathrm{N}$ topdressing had no significant effects on ADF content, but significant $(p<0.01)$ effects on NDF were noted in the $\mathrm{C} 3$ treatment (Table 2).

Table 2. Effect of clipping frequency and $\mathrm{N}$ topdressing during the growing period on crude protein $(\mathrm{CP})$, acid detergent fiber (ADF), and neutral detergent fiber (NDF) content of forage sorghum.

\begin{tabular}{ccccccc}
\hline & CP (\%) & \multicolumn{3}{c}{ ADF (\%) } & NDF (\%) \\
\hline N1 & C3 & C4 & C3 & C4 & C3 & C4 \\
N0 & $7.6 \mathrm{a}$ & $6.0 \mathrm{a}$ & $28.1 \mathrm{a}$ & $30.9 \mathrm{a}$ & $55.9 \mathrm{a}$ & $48.8 \mathrm{~b}$ \\
Significance & $p .6 \mathrm{~b}$ & $4.2 \mathrm{~b}$ & $27.8 \mathrm{a}$ & $29.3 \mathrm{a}$ & $56.6 \mathrm{a}$ & $56.3 \mathrm{a}$ \\
LSD (0.05) & 0.001 & $p<0.001$ & ns & Ns & Ns & $p<0.01$ \\
CV (\%) & 7.6 & 1.6 & 1.5 & 6.1 & 2.8 & 1.6 \\
\hline
\end{tabular}

Means in columns indicated by the same letter are not significantly different at $p=0.05 . \mathrm{CV}=$ coefficient of variation. 


\subsubsection{Grazing Quality at Termination}

There was a significant $(p<0.001)$ interaction between clipping frequency and $\mathrm{N}$ topdressing on the $\mathrm{CP}$ content. Nitrogen topdressing significantly improved $\mathrm{CP}$ content of forage sorghum in $\mathrm{C} 3$ and $\mathrm{C} 4$, but not with $\mathrm{C} 1$ and $\mathrm{C} 2$ (Figure 2).

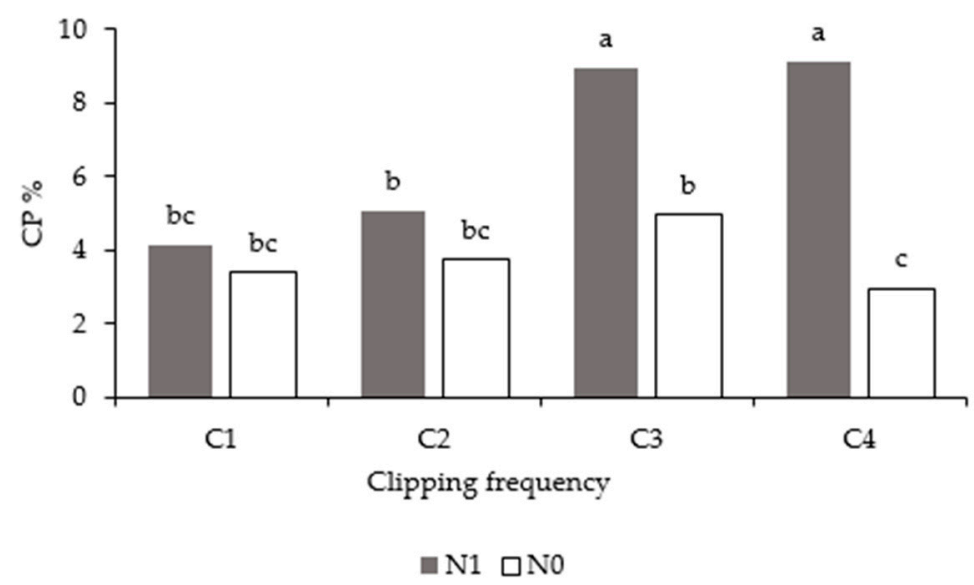

Figure 2. Effect of clipping frequency and $\mathrm{N}$ topdressing on $\mathrm{CP}$ content in forage sorghum at termination. Different lower case letters show significant differences at $p<0.05$. LSD $0.05=1.02$.

Meanwhile, it could be deduced from the results of the study that there was no interaction between clipping frequency and $\mathrm{N}$ topdressing on $\mathrm{ADF}$ and NDF content at termination stage. The main effect of $\mathrm{N}$ topdressing significantly $(p<0.001)$ affected ADF and NDF content. Higher mean ADF and $\mathrm{NDF}$ values were obtained in forage sorghum that was not supplemented with $\mathrm{N}$ as compared to the treatments that had $\mathrm{N}$ added. Furthermore, results indicated that treatments that were not topdressed had $35.7 \%$ ADF content, which was $11.2 \%$ higher than treatments that had no N topdressing. Similarly, NDF content was $9.2 \%$ higher in non-topdressed treatments as compared to topdressed treatments, which had 50.9\% NDF content.

Clipping frequency significantly affected ADF $(p<0.05)$ and NDF $(p<0.01)$. All the ADF and NDF values obtained fell within the recommended range of forage quality [11], as shown in Table 3.

Table 3. Effect of clipping frequency on ADF and NDF in forage sorghum harvested at termination.

\begin{tabular}{cccc} 
& ADF (\%) & NDF (\%) \\
\cline { 2 - 3 } C1 & $31.9 \mathrm{~b}$ & $54.8 \mathrm{a}$ \\
$\mathrm{C} 2$ & $34.1 \mathrm{ab}$ & $53.2 \mathrm{ab}$ \\
$\mathrm{C} 3$ & $35.4 \mathrm{a}$ & $51.3 \mathrm{~b}$ \\
$\mathrm{C} 4$ & $34.1 \mathrm{ab}$ & $53.6 \mathrm{a}$ \\
\cline { 2 - 3 } & Significance & $p<0.05$ & $p<0.01$ \\
Means in columns indicated by the same lowercase letter are not significantly different at $p=0.05$.
\end{tabular}

\subsection{On-Farm Experiments}

\subsubsection{Biomass Yield Measured during the Growing Period}

Findings revealed that treatments clipped at 28 DAE, C2, yielded average biomass of 2.2 and $2.3 \mathrm{t} \mathrm{ha}^{-1}$ (data not shown) in 2016-2017 and 2017-2018, respectively. During the season, biomass was measured at $\mathrm{C} 3$ and $\mathrm{C} 4$ and analyzed as one-way ANOVA (Table 4). There were no significant differences $(p>0.05)$ in biomass in either C3 or C4 in 2016-2017 and 2017-2018 seasons. 
Table 4. Effect of clipping frequency and $\mathrm{N}$ topdressing on the biomass yield of forage sorghum harvested during the growing period.

\begin{tabular}{|c|c|c|c|c|}
\hline \multirow[b]{2}{*}{ Clipping Frequency } & \multicolumn{2}{|c|}{ 2016-2017 Season (t ha-1) } & \multicolumn{2}{|c|}{ 2017-2018 Season $\left(\mathrm{t} \mathrm{ha}^{-1}\right)$} \\
\hline & $\mathrm{C} 3$ & $\mathrm{C} 4$ & $\mathrm{C} 3$ & $\mathrm{C} 4$ \\
\hline N1 & $1.3 \mathrm{a}$ & $0.97 \mathrm{a}$ & $1.2 \mathrm{a}$ & $1.0 \mathrm{a}$ \\
\hline No & $1.1 \mathrm{a}$ & $0.95 \mathrm{a}$ & $1.2 \mathrm{a}$ & $0.7 \mathrm{a}$ \\
\hline LSD (0.05) & 0.2 & 0.1 & 0.2 & 0.5 \\
\hline Significance & ns & Ns & ns & ns \\
\hline $\mathrm{CV}(\%)$ & 18 & 13 & 11 & 15 \\
\hline
\end{tabular}

Means in columns indicated by the same letter are not significantly different at $p=0.05 . \mathrm{CV}=$ coefficient of variation.

\subsubsection{Biomass Yield Harvested}

At termination stage there was a significant interaction between clipping frequency and $\mathrm{N}$ topdressing on the biomass yield in both 2016-2017 $(p<0.05)$ and 2017-2018 $(p<0.001)$ seasons. In 2016-2017 season, application of $\mathrm{N}$ topdressing significantly improved biomass yield for C2 at termination stage but had no effect at $\mathrm{C} 1, \mathrm{C} 3$, or $\mathrm{C} 4$, as shown in Figure 3.

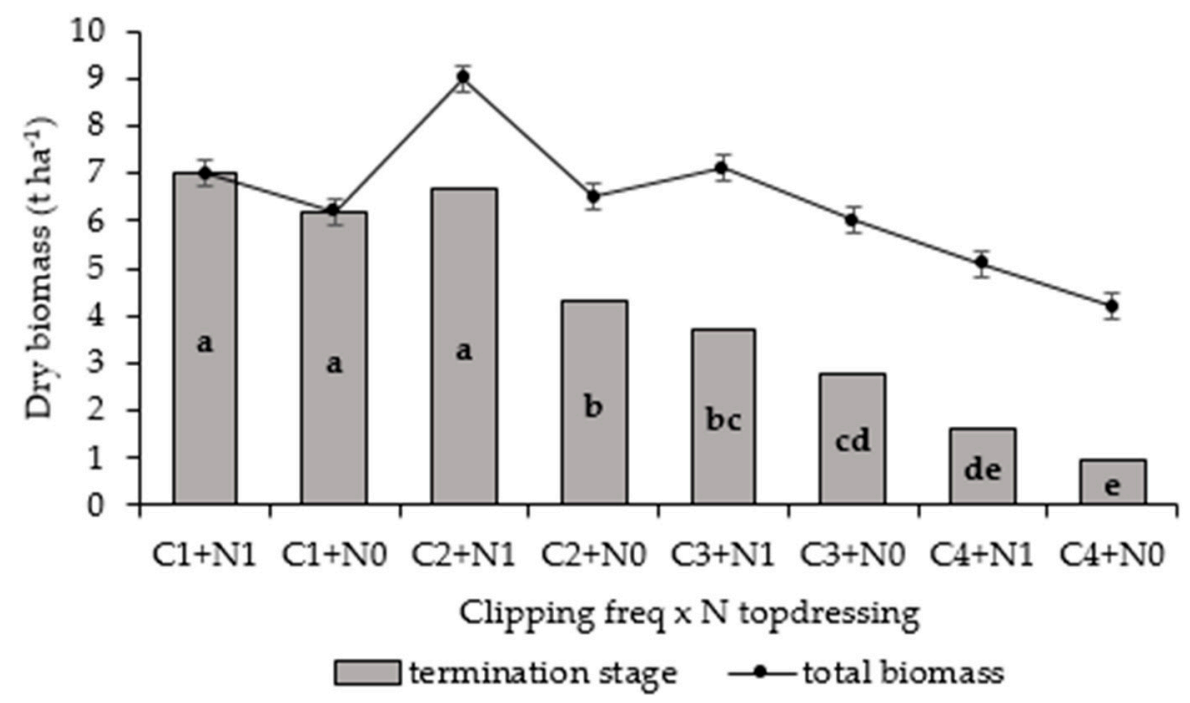

Figure 3. Effect of clipping frequency and $\mathrm{N}$ topdressing on the dry biomass present at termination stage and on the total dry biomass harvested in 2016-2017 season. Different lowercase letters inside the bars show significant differences at $p<0.05$. LSD $=0.8$.

In 2017-2018 season $\mathrm{N}$ topdressing significantly increased biomass at C1 and C2 but did not have a significant effect $(p>0.05)$ on biomass at $C 3$ and $C 4$, as shown in Figure 4.

Furthermore, results show that the main effects of clipping frequency and $\mathrm{N}$ topdressing were significant $(p<0.001)$ in both seasons. For instance, increasing clipping frequency resulted in decreased forage sorghum biomass yield that was standing at termination stage, with the lowest observed in $\mathrm{C} 4+\mathrm{N} 0$ in both seasons. Standing biomass of $>6 \mathrm{t} \mathrm{ha}^{-1}$ was realized with the control and C2 $+\mathrm{N} 1$. The latter treatment yielded the same as the control in 2016-2017 but was 8.6\% lower in 2017-2018.

There was a significant interaction between clipping frequency and $\mathrm{N}$ topdressing in the total biomass of forage sorghum harvested in both 2016-2017 $(p<0.05)$ and 2017-2018 $(p<0.001)$ seasons. Although all the $\mathrm{N}$ topdressed treatments had significantly higher biomass yields than non-topdressed (Figures 3 and 4), the results showed that the magnitude of difference was highest in C2 than in the rest of the treatments in both seasons. The highest total dry biomass harvested in forage sorghum was observed under C2 + N1, whilst the lowest was in C4 + N0, as illustrated in Figures 3 and 4. The main 
effects of clipping frequency and $\mathrm{N}$ topdressing also significantly $(p<0.001)$ affected total biomass yield of forage sorghum harvested.
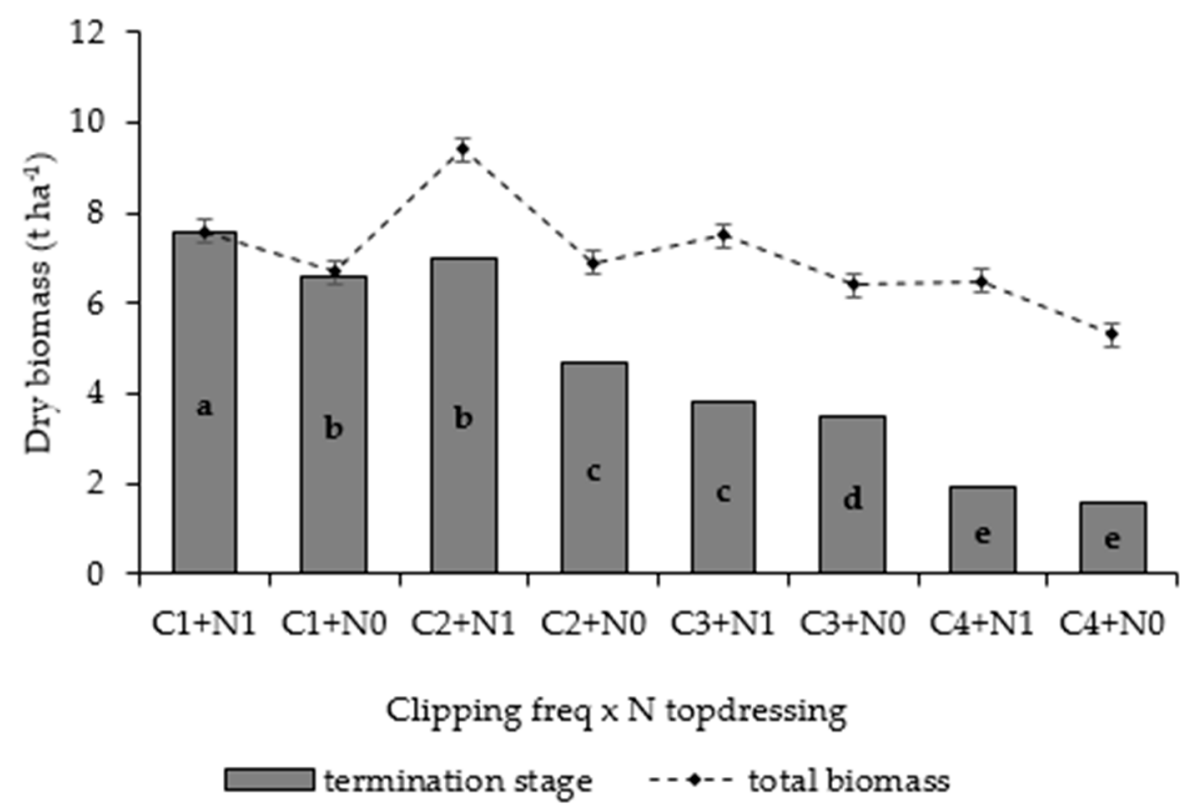

Figure 4. Effect of clipping frequency and $\mathrm{N}$ topdressing on the dry biomass present at termination stage and on the total dry biomass harvested in 2017-2018 season. Different lowercase letters inside the bars show significant differences at $p<0.05$. LSD $=0.3$.

\section{Discussion}

Overall, the experiments carried out demonstrated the potential of forage sorghum as a dual purpose cover and forage crop for the central EC Province of SA environment. The significant increase in root biomass for the treatments that were clipped once and did not receive $\mathrm{N}$ topdressing can be attributed to the development of exploratory root systems. According to Parra-Londono et al. [29], when sorghum is subjected to environments where water, phosphorus, or $\mathrm{N}$ are limited, sorghum responds by developing exploratory roots that have the ability to scavenge nutrients in untapped zones of the soil. Roots and stolon contain plant reserve, which is composed mostly of non-structural carbohydrates (NSC). These NSC are used in the regrowth activity of a plant after removal of herbage [19]. In this study, root biomass decreased with increasing clipping frequency. The findings of the study align with research by Guo et al. [30], who posit that increasing clipping frequency reduces carbohydrate formation from photosynthesis activity, and this limits $\mathrm{N}$ uptake until appropriate plant $\mathrm{C}$ to $\mathrm{N}$ ratio is restored. The results of the study suggest that the available carbohydrates in the reserves are, thus, directed towards above ground biomass regrowth rather than root expansion. This explains the observed decrease in root biomass with increasing clipping frequency. The decrease in root biomass can have negative effects on soil quality, as the roots form the main source $\mathrm{C}$ needed in maintaining or improving soil organic matter [31]. Similar results of decreasing root biomass with increasing clipping frequency are also reported by Zuffo et al. [32].

Crude protein is an important forage quality parameter. The observed higher average $\mathrm{CP}$ content in treatments that received $\mathrm{N}$ topdressing during the growing period can be attributed to the high involvement of $\mathrm{N}$ in the protein synthesis, as suggested by McDonald et al. [15]. The decreasing $\mathrm{CP}$ content with increasing clipping frequency during the growing period can be explained by the decreased $\mathrm{N}$ uptake by the roots under limited carbon environments. Similar results of decreasing CP content with increasing herbage removal were also reported by Raynor et al. [33] in forages that were grazed by large herbivores. At termination stage, the highest $\mathrm{CP}$ values were obtained in $\mathrm{C} 3+\mathrm{N} 1$ and $\mathrm{C} 4+\mathrm{N} 1$. These results relate to the early stages of growth which $\mathrm{C} 3+\mathrm{N} 1$ and $\mathrm{C} 4+\mathrm{N} 1$ were at the 
time of termination, as compared to the rest. Treatments $C 1$ and $C 2$ in this study were more advanced in growth at termination stage than C3 and C4, and according to Mwangi et al. [34], CP decreases as the crop advances towards physiological maturity. The addition of $\mathrm{N}$ further enhanced protein synthesis, which therefore significantly increased CP of C3 + N1 and C4 + N1.

The findings showed that $\mathrm{N}$ topdressing had insignificant effects on crude fiber content during the growing period. Similar findings were also reported by Eltelib [35]. The accepted ranges of crude fiber are $<45 \%$ for ADF and $<65 \%$ NDF [11]. Emerging results for this study indicated that all the $\mathrm{ADF}$ and NDF values observed during the growing season and at termination fit within these ranges. The observed decrease in ADF and NDF content with $\mathrm{N}$ topdressing in forage sorghum has also been reported by Reddy et al. [36]. High crude fiber content in crop residue is associated with longer residue persistence when used for soil cover due to high lignin amounts [15]. However, in this study, treatments with the highest ADF and NDF content do not support a win-win function required from forage sorghum due to low biomass levels observed from these treatments, as well as low CP content.

The observed increase in forage sorghum biomass in $\mathrm{C} 2$ at termination stage in both seasons is due to $\mathrm{N}$ topdressing. Increasing $\mathrm{N}$ application in plants results in increased chloroplast protein, chlorophyll content, and leaf area, which raises the rate of photosynthesis [15]. Further $\mathrm{N}$ topdressing in $\mathrm{C} 3$ and $\mathrm{C} 4$ forage sorghum treatments did not significantly increase biomass yield, and this could be due to low $\mathrm{C} / \mathrm{N}$ ratio. The removal of herbage in some grass species reduces carbon concentration in the plant, and this decreases $\mathrm{N}$ uptake by the plant until correct $\mathrm{C} / \mathrm{N}$ ratio is restored [37]. This can, therefore, explain the absence of significant differences due to $\mathrm{N}$ topdressing in $\mathrm{C} 3$ and $\mathrm{C} 4$ forage sorghum treatments.

The results at termination stage showed that increasing clipping frequency resulted in decreasing vegetative biomass yield that was standing at harvest. The results suggest a longer recovery period in $\mathrm{C} 1$ and $\mathrm{C} 2$ treatments as compared to $\mathrm{C} 3$ and $\mathrm{C} 4$. The recovery period allows for growth of vegetative structures such as leaves, as well as increasing plant height [38]. Furthermore, $\mathrm{N}$ is highly involved in the development of vegetative structures, and this can explain the higher yields obtained under topdressed treatments in forage sorghum as compared to the non-topdressed. For the purposes of reducing water runoff and erosion and increasing water infiltration and retention, residue amounts of $2 \mathrm{t} \mathrm{ha}^{-1}$ have been suggested [7-10]. From this study, forage sorghum treatments $\mathrm{C} 1, \mathrm{C} 2$, and C3 produced biomass yield that was above the minimum threshold figure $\left(>2 \mathrm{tha}^{-1}\right)$ for soil cover benefits.

Subtracting the biomass yield standing at harvest from the total biomass yield harvested gave an indication of possible biomass levels that could be fed to livestock. Highest biomass for livestock feed was observed in $\mathrm{C} 4$, and this can be attributed to the repeated clipping of vegetative biomass matter. Although C4 produced highest biomass yield for livestock feed, $\mathrm{C} 4$ cannot perform a dual purpose of soil cover and livestock feed, since it produced yields that were less than $2 \mathrm{tha}^{-1}$ at termination stage. Furthermore, the greenhouse experiment showed that $C 4$ treatments of forage sorghum clipped during the growing period had $\mathrm{CP}$ levels that were below the critical figure, an indication that this is not ideal for livestock feeding. The findings of the study suggest that treatment $\mathrm{C} 3+\mathrm{N} 1$ makes the best choice for livestock feed, and produces forage biomass of about $3.6 \mathrm{t} \mathrm{ha}^{-1}$. In addition, the results from the greenhouse reveal that forage sorghum C $3+\mathrm{N} 1$ had grazing quality within the acceptable range for livestock feed at termination stage. Since forage sorghum C $3+\mathrm{N} 1$ produced biomass of about $3.7 \mathrm{t} \mathrm{ha}^{-1}$ at termination, the $1.7 \mathrm{t} \mathrm{ha}^{-1}$ "surplus" can be directed towards livestock feed, to give a total of $5.3 \mathrm{t} \mathrm{ha}^{-1}$. These results infer that resource-constrained farmers can uptake a C2 + N0 combination, which provides $2.2 \mathrm{tha}^{-1}$ livestock forage biomass and $4.4 \mathrm{t} \mathrm{ha}^{-1}$ dry matter for soil cover. On the other hand, greenhouse experiment suggests that grazing quality obtained from $\mathrm{C} 2+\mathrm{N} 0$ forage sorghum at termination stage was below the critical threshold value. Therefore, no extra biomass can be removed at termination stage for the purposes of livestock feed. 


\section{Conclusions}

Clipping forage sorghum twice during the growing season, at 28 and 42 DAE, and applying N topdressing is a viable management system under the central EC South African climate, where biomass is needed for livestock feed and soil cover. Increasing clipping frequency from clipping twice (C3) to thrice (C4) significantly decreased both the biomass standing at termination stage and the total biomass harvested. The study further concludes that not applying $\mathrm{N}$ topdressing significantly lowers grazing quality as well as the biomass yield that can be observed. Clipping twice during the growing season and applying $\mathrm{N}$ topdressing $(\mathrm{C} 3+\mathrm{N} 1)$ offered the best treatment combination and supplied $2 \mathrm{tha}^{-1}$ of soil cover biomass and about $5.3 \mathrm{t} \mathrm{ha}^{-1}$ biomass for livestock feed. This management combination provides the minimum required crop residue biomass for soil cover, as well as provides the highest biomass yield with acceptable grazing quality during both the growing period and at termination stage.

Author Contributions: K.J. designed and set up the study, collected data, analyzed data, and wrote the manuscript. Z.M. collected and analyzed data. L.M. reviewed and edited the paper. C.C. was principal investigator, performed design setup and supervision, analyzed data, and wrote and edited the draft manuscript. All authors have read and agreed to the published version of the manuscript.

Funding: This research was funded by the National Research Foundation (NRF) of South Africa (grant number PR-RTF180208310948) and the Govan Mbeki Research and Development Center (GMRDC).

Conflicts of Interest: The authors declare no conflict of interest.

\section{References}

1. Ighodaro, I.; Yusuf, F. The impact of soil erosion on agricultural potential and performance of Sheshegu community farmers in the Eastern Cape of South Africa. J. Agric. Sci. 2013, 5, 140-147. [CrossRef]

2. Khapayi, M.; Celliers, P.R. Factors limiting and preventing emerging farmers to progress to commercial agricultural farming in the King William's Town area of the Eastern Cape Province, South Africa. South Africa Tydskr. Landbouvoorl. S. Afr. J. Agric. Ext. 2016, 44, 25-41. [CrossRef]

3. Department of Agriculture, Forestry \& Fisheries. Trends in the Agricultural Sector 2017; Directorate of Communication Services: Pretoria, South Africa, 2018.

4. $\quad$ Baets, S.; Poesen, J.J.; Meersmans, J.J.; Serlet, L.L. Cover crops and their erosion-reducing effects during concentrated flow erosion. Catena 2011, 85, 237-244. [CrossRef]

5. Brust, J.; Claupein, W.; Gerhards, R. Growth and weed suppression ability of common and new cover crops in Germany. Crop Prot. 2014, 63, 1-8. [CrossRef]

6. Turmel, M.; Speratti, A.; Baudron, F.; Verhulst, N.; Govaerts, B. Crop residue management and soil health: A systems analysis. Agric. Syst. 2015, 134, 6-16. [CrossRef]

7. Choudhary, M.; Rana, K.S.; Meena, M.C.; Bana, R.S.; Jakhar, P.; Ghasal, P.C.; Verma, R.K. Changes in physico-chemical and biological properties of soil under conservation agriculture based pearl millet-Mustard cropping system in rain fed semi-arid region. J. Arch. Agron. Soil Sci. 2018, 65, 911-927. [CrossRef]

8. Swella, G.B.; Ward, P.R.; Siddique, K.H.M.; Flower, K.C. Combinations of tall standing and horizontal residue affect soil water dynamics in rain-fed conservation agriculture systems. Soil Tillage Res. 2015, 147, 30-38. [CrossRef]

9. Nichols, V.; Verhulst, N.; Cox, R.; Govaerts, B. Weed dynamics and conservation agriculture principles: A review. Field Crops Res. 2015, 183, 56-68. [CrossRef]

10. Ranaivoson, L.; Naudin, K.; Ripoche, A.; Affholder, F.; Rabeharisoa, L.; Corbeels, M. Agro-ecological functions of crop residues under conservation agriculture. A review. Agron. Sustain. Dev. 2017, 37, 26. [CrossRef]

11. Blezinger, S. Developing Sound Forage Analyses a Program, 1999. Available online: http://www.cattletoday. com/archive/1999/September/Cattle_Today20.shtml (accessed on 27 January 2018).

12. Kumar, D.; Chaplot, P.C. Effect of fertility levels on quality of multi-cut forage sorghum genotypes. Forage Res. 2015, 40, 251-253.

13. Rana, D.S.; Singh, B.; Gupta, K.; Dhaka, A.K.; Pahuja, S.K. Effect of fertility levels on growth, yield and quality of multicut forage sorghum [Sorghum bicolor (1.) Moench] genotypes. Forage Res. 2013, 39, 36-38. 
14. Roy, P.R.S.; Khandaker, Z.H. Effect of phosphorus fertilizer on yield and nutritional value of sorghum (sorghum bicolor) fodder at three cuttings. Bangladesh J. Anim. Sci. 2010, 39, 106-115. [CrossRef]

15. McDonald, P.; Edwards, R.A.; Greenhalgh, J.F.D.; Morgan, C.A.; Sinclair, L.A.; Wilkinson, R.G. Animal Nutrition, 7th ed.; Prentice Hall: Upper Saddle River, NJ, USA, 2011.

16. Nirmal, S.S.; Dudhade, D.D.; Solanke, A.V.; Gadakh, S.R.; Bhakare, B.D.; Hasure, R.R.; Gore, S.B. Effect of nitrogen levels on growth and yield of forage sorghum [Sorghum bicolor (1.) moench] varieties. Int. J. Sci. 2016, 5, 2999-3004.

17. Tang, C.; Yang, X.; Chen, X.; Ameen, A.; Xie, G. Sorghum biomass and quality and soil nitrogen balance response to nitrogen rate on semiarid marginal land. Field Crops Res. 2018, 215, 12-22. [CrossRef]

18. Almeida, V.O.; Carneiro, R.V.; Carvalho, M.A.M.; Figueiredo-Ribeiro, R.C.L.; Moraes, M.G. Diversity of non-structural carbohydrates in the underground organs of five Iridaceae species from the Cerrado (Brazil). S. Afr. J. Bot. 2015, 96, 105-111. [CrossRef]

19. Liu, W.; Su, J.; Li, S.; Lang, X.; Huang, X. Non-structural carbohydrates regulated by season and species in the subtropical monsoon broadleaved evergreen forest of Yunnan Province, China. Sci. Rep. 2018, 8, 1083. [CrossRef]

20. Mapfumo, E.; Naeth, M.A.; Baron, V.S.; Dick, A.C.; Chanasyk, D.S. Grazing impacts on litter and roots: Perennial versus annual grasses. J. Range Manag. 2002, 5, 16-22. [CrossRef]

21. Soil Classification working group. Soil Classification. In A Taxonomic System for South Africa; Department of Agricultural Development: Pretoria, South Africa, 1991.

22. IUSS Working Group WRB. World Reference Base for Soil Resources, 2nd ed.; World Soil Resources Reports No. 103; FAO: Rome, Italy, 2006; ISBN 92-5-105511-4.

23. Agri Laboratory Association of Southern Africa (AgriLASA). Soil Handbook; Agri Laboratory Association of Southern Africa: Pretoria, South Africa, 2004.

24. Mnkeni, P.N.S.; Gichangi, E.M. A Practical Teaching Manual for Plant Analysis; University of Fort Hare, Faculty of Science and Agriculture, Department of Agronomy: Alice, South Africa, 2008.

25. Mehlich, A. Uniformity of expressing soil test results. A case for calculating results on a volume basis. Commun. Soil Sci. Plant Anal. 1972, 3, 417-424. [CrossRef]

26. Sher, A.; Hassan, F.; Ali, H.; Hassan, W. Seed rate and nitrogen application effects on production and brix value of forage sorghum cultivars. Grassl. Sci. 2015, 62, 119-127. [CrossRef]

27. Department of Agriculture, Forestry \& Fisheries. Sorghum Production Guideline, 2010. Available online: https://www.nda.agric.za/docs/Brochures/prodGuideSorghum.pdf (accessed on 16 March 2016).

28. Mandiringana, O.T.; Mnkeni, P.N.S.; Mkile, Z.; Van Averbeke, W.; Van Ranste, E.; Verplancke, H. Mineralogy and fertility status of selected soils of the Eastern Cape Province, South Africa. Commun. Soil Sci. Plant Anal. 2005, 36, 2431-2446. [CrossRef]

29. Parra-Londono, S.; Kavka, M.; Samans, B.; Snowdon, R.; Wieckhorst, S.; Uptmoor, R. Sorghum root-system classification in contrasting $\mathrm{P}$ environments reveals three main rooting types and root-architecture-related marker-trait associations. Ann. Bot. 2018, 121, 267-280. [CrossRef] [PubMed]

30. Guo, Q.; Turnbull, M.H.; Song, J.; Roche, J.; Novak, O.; Späth, J.; Jameson, P.E.; Love, J. Depletion of carbohydrate reserves limits nitrate uptake during early regrowth in Lolium perenne L. J. Exp. Bot. 2017, 68, 1569-1583. [CrossRef]

31. Sainju, U.M.; Singh, B.P.; Whitehead, W.F. Tillage, cover crops, and nitrogen fertilization effects on cotton and sorghum root biomass, carbon, and nitrogen. Agron. J. 2005, 97, 1279-1290. [CrossRef]

32. Zuffo, A.M.; Júnior, J.M.Z.; da Silva, J.A.; dos Santos, D.S.; Oliveira, J.B.D.; Zambiazzi, E.V.; Bruzi, A.T.; Vilela, N.J.D.; Vilela, G.L.D.; Ferreira, A.C.G. Morphoagronomic traits of BRS 610 sorghum submitted to artificial defoliation. Afr. J. Agric. Res. 2015, 10, 3798-3803.

33. Raynor, E.J.; Joern, A.; Nippert, J.B.; Briggs, J.M. Forage decisions underlying restricted space use: Effects of fire and forage maturation on large herbivore nutrient uptake. Ecol. Evol. 2016, 6, 5843-5853. [CrossRef]

34. Mwangi, P.G.; Gachuiri, C.K.; Mbugua, P.N. Effect of growth stage on fodder yield and quality of dual purpose sorghum. Trop. Drylands 2017, 1, 100-104. [CrossRef]

35. Eltelib, H.A.; Hamad, M.A.; Ali, E.E. The effect of nitrogen and phosphorus fertilization on growth, yield and quality of forage maize (Zea mays L.). J. Agron. 2006, 5, 515-518. 
36. Reddy, B.V.S.; Reddy, P.S.; Bidingera, F.; Blummel, M. Crop management factors influencing yield and quality of crop residues. Field Crops Res. 2003, 84, 57-77. [CrossRef]

37. Ferraro, D.O.; Oesterheld, M. Effect of defoliation on grass growth. Quant. Rev. Oikos 2002, 98, 125-133.

38. Legwaila, G.M.; Sekgwane, S.; Mathowa, T.; Mojeremane, W. Agronomic performance of sorghum after panicle removal. Int. J. Plant Soil Sci. 2016, 10, 1-7. [CrossRef] 